\title{
Vitamin D deficiency is associated with higher disease activity and the risk for uveitis in juvenile idiopathic arthritis - data from a German inception cohort
}

\author{
Claudia Sengler ${ }^{1 *+} \mathbb{B}$, Julian Zink ${ }^{1 \dagger}$, Jens Klotsche ${ }^{1,2}$, Martina Niewerth ${ }^{1}$, Ina Liedmann ${ }^{1}$, Gerd Horneff ${ }^{3,4}$, \\ Christoph Kessel $^{5}$, Gerd Ganser ${ }^{6}$, Angelika Thon ${ }^{7}$, Johannes-Peter Haas ${ }^{8}$, Anton Hospach ${ }^{9}$, \\ Frank Weller-Heinemann ${ }^{10}$, Arnd Heiligenhaus ${ }^{11,12}$, Dirk Foell ${ }^{5}$, Angela Zink ${ }^{1,13}$ and Kirsten Minden ${ }^{1,13}$
}

\begin{abstract}
Objective: The objective was to evaluate the $25(\mathrm{OH})$ vitamin $\mathrm{D}(25(\mathrm{OH}) \mathrm{D})$ status of patients with juvenile idiopathic arthritis (JIA) and determine whether the $25(\mathrm{OH}) \mathrm{D}$ level is associated with disease activity and the course of JIA.

Methods: Patients $\leq 16$ years of age with recently diagnosed JIA ( $<12$ months) were enrolled in the inception cohort of patients with newly diagnosed JIA (ICON), an ongoing prospective observational, controlled multicenter study started in 2010. Clinical and laboratory parameters were ascertained quarterly during the first year and halfyearly thereafter.

Of the 954 enrolled patients, 360 patients with two blood samples taken during the first 2 years after inclusion and with follow up of 3 years were selected. The serum 25(OH)D levels were determined and compared with those of subjects from the general population after matching for age, sex, migration status and the month of blood-drawing.
\end{abstract}

Results: Nearly half of the patients had a deficient 25(OH)D level $(<20 \mathrm{ng} / \mathrm{ml})$ in the first serum sample and a quarter had a deficient level in both samples. Disease activity and the risk of developing JIA-associated uveitis were inversely correlated with the $25(\mathrm{OH}) \mathrm{D}$ level $(\beta=-0.20,95 \% \mathrm{Cl}-0.37 ; 0.03$, hazard ratio $0.95,95 \% \mathrm{Cl} 0.91 ; 0.99$, respectively).

Conclusion: In this study, 25(OH)D deficiency was common and associated with higher disease activity and risk of developing JIA-associated uveitis. Further studies are needed to substantiate these results and determine whether correcting 25(OH)D deficiency is beneficial in JIA.

Keywords: Vitamin D, Juvenile idiopathic arthritis, Disease activity, Uveitis

\section{Key messages}

- Vitamin D deficiency was common, as it was found in $44 \%$ of patients with juvenile idiopathic arthritis (JIA) and even in $62 \%$ of healthy peers

- Low levels of 25(OH)D in patients with JIA were associated with higher disease activity and higher risk of developing JIA-associated uveitis

\footnotetext{
* Correspondence: sengler@drfz.de

${ }^{+}$Claudia Sengler and Julian Zink contributed equally to this work.

'German Rheumatism Research Center, a Leibniz Institute, Charitéplatz 1,

10117 Berlin, Germany

Full list of author information is available at the end of the article
}

\section{Introduction}

Over the last decade, it has become clear that vitamin D is more than the "bone vitamin" that regulates calcium homeostasis and bone mineralization. In addition to its pleiotropic functions in different cells and tissues, the differentiation, polarization and activity of immune cells are affected by $1,25(\mathrm{OH})_{2}$ vitamin D3 [1]. This is the biologically active form that results from the double hydroxylation of cholecalciferol that is ingested or produced in the skin by ultraviolet sunlight. Several studies have shown an association between low vitamin $\mathrm{D}$, mostly measured as $25(\mathrm{OH})$ vitamin D3 $(25(\mathrm{OH}) \mathrm{D})$, and higher incidence and severity of autoimmune disorders, such as type 1

(c) The Author(s). 2018 Open Access This article is distributed under the terms of the Creative Commons Attribution 4.0 International License (http://creativecommons.org/licenses/by/4.0/), which permits unrestricted use, distribution, and 
diabetes mellitus, chronic inflammatory bowel disease, rheumatoid arthritis (RA) and multiple sclerosis [1]. Nisar et al. conducted a meta-analysis of several studies evaluating patients with JIA with reported serum vitamin D levels [2]; however, the parameters that were measured $\left(25(\mathrm{OH}) \mathrm{D}, 1,25(\mathrm{OH})_{2} \mathrm{D} 3\right)$, clinical outcomes and the cutoff values that were used differed substantially. Currently, the measurement of $25(\mathrm{OH}) \mathrm{D}$ is considered standard because it is stable and reflects the vitamin D provision of the last weeks to months. In our study, we wanted to (1) evaluate the $25(\mathrm{OH}) \mathrm{D}$ level in patients with newly diagnosed JIA and compare it with that in individuals from the general population; (2) analyze whether disease activity is correlated with the $25(\mathrm{OH}) \mathrm{D}$ level and (3) determine whether the $25(\mathrm{OH}) \mathrm{D}$ level might predict the disease course.

\section{Methods}

\section{Patients}

The inception cohort of newly diagnosed patients with JIA (ICON) has been described in detail elsewhere [3]. Briefly, patients diagnosed with JIA according to the International League of Associations for Rheumatology (ILAR) criteria [4] over the previous 12 months were included in this prospective, multicenter, observational cohort study. On the basis of standardized questionnaires and pediatric rheumatologic assessments, clinical and demographic data and information on medication use were collected every 3 months during the first year and every 6 months thereafter. Vitamin D supplementation was not ascertained. The active joint count, the physician's global assessment of disease activity on a numeric rating scale (NRS, $0-10,0=$ best), the parents' global assessment of wellbeing (NRS) and the antinuclear antibody (ANA) status (negative/positive based on the standards of the local laboratory that carried out this assay) were recorded. A slit lamp examination was performed by an ophthalmologist every 3-6 months according to the screening guidelines by the German study group "Uveitis in childhood" [5], and the findings were documented on a specific uveitis documentation form. Patients 8 years of age and older and their parents provided informed assent/consent for participation. The study was approved by the ethics committee of the Charite Universitätsmedizin Berlin.

\section{Serum samples}

Serum samples were taken as part of routine laboratory controls in ICON and were collected, frozen and stored at the ICON biobank at the University of Münster, Germany, until they were shipped to Berlin, Germany, to perform the $25(\mathrm{OH}) \mathrm{D}$ assay for all samples at the same time at a medical laboratory. For our analysis, we selected patients for whom a pair of serum samples was available. The first sample was collected at a visit that occurred between baseline and the 9-month follow up
(94\% at baseline or at 3-month follow up), and the second sample was collected at a visit that occurred between the 3-month follow up and the 36-month follow up (92\% until the 1-year follow up), with a mean interval of 7 months (SD 5) between blood draws. The time points for serum collection in male and female subjects were equally distributed in winter (October-March) and summer (April-September).

\section{5(OH) vitamin $D$ measurement and cutoff values}

The LIAISON $25 \mathrm{OH}$ Vitamin D TOTAL Assay (direct competitive chemiluminescence immunoassay, DiaSorin Inc., Stillwater, MN, USA) was used to quantitatively determine the $25(\mathrm{OH}) \mathrm{D}$ level in the serum samples. The measurement range of this assay ranges from $4 \mathrm{ng} / \mathrm{ml}(10$ $\mathrm{nmol} / \mathrm{l})$ to $150 \mathrm{ng} / \mathrm{ml}(375 \mathrm{nmol} / \mathrm{l})$. To compare the 25(OH)D levels of patients with healthy subjects, we used data from the German National Health Interview and Examination Survey for Children and Adolescents (KIGGS), which was conducted from May 2003 to May 2006, to obtain representative data on health status and selected laboratory values of children and adolescents aged 0-17 years across Germany (for details, please refer to [6]). Valid measurements of serum $25(\mathrm{OH}) \mathrm{D}$, also performed with the LIAISON $25 \mathrm{OH}$ Vitamin D TOTAL Assay, from 10,015 participants of this study were available from public-use files. Control subjects were matched with a ratio 1: 1 for age, sex, month of blood draw and migration background. The latter was defined as "mother's and/or father's country of origin not Germany". This variable integrates several factors like skin pigmentation but also cultural habits like type of clothing and veiling that possibly influence the vitamin $\mathrm{D}$ production in the skin and thereby the 25(OH)D serum level [7].

According to the data from several studies that included clinical (e.g., fracture risk) and laboratory parameters (e.g., calcium uptake), it has been proposed vitamin D deficiency as $25(\mathrm{OH}) \mathrm{D}<20 \mathrm{ng} / \mathrm{ml}(<50 \mathrm{nmol} / \mathrm{l})$ [8-10]. Using the negative relationship between the serum $25(\mathrm{OH}) \mathrm{D}$ and parathyroid hormone $(\mathrm{PTH})$, it was shown that $\mathrm{PTH}$ began to increase at $25(\mathrm{OH}) \mathrm{D}$ of $75(30 \mathrm{ng} / \mathrm{ml})$ or $78 \mathrm{nmol} / \mathrm{l}(31.2$ $\mathrm{ng} / \mathrm{ml})[11,12]$. Holick et al. determined the following categories that integrate both cutoff values that we used for our analysis: 25(OH)D deficiency, $<20 \mathrm{ng} / \mathrm{ml}(<50 \mathrm{nmol} / \mathrm{l})$; $25(\mathrm{OH}) \mathrm{D}$ insufficiency, $20-29 \mathrm{ng} / \mathrm{ml}$ and $25(\mathrm{OH}) \mathrm{D}$ sufficiency, $\geq 30 \mathrm{ng} / \mathrm{ml}$ [13]. A $25(\mathrm{OH}) \mathrm{D}$ level $<20 \mathrm{ng} / \mathrm{ml}$ or $\geq$ $30 \mathrm{ng} / \mathrm{ml}$ in both of the patient's serum samples was defined as stable deficient or stable sufficient vitamin D status, respectively, implicating prolonged deficiency or sufficiency of vitamin D.

\section{Outcome and statistics}

The disease activity of patients with JIA was measured by the clinical Juvenile Arthritis Disease Activity Score (cJADAS-10), a composite score $(0-30,0=$ best) based 
on the physician's global assessment of disease activity, the parents' global assessments of wellbeing, and the number of active joints up to a maximum of 10, according to McErlane et al. [14]. For the present analysis, (a) the disease activity, (b) the development of the extended form of oligoarthritis and (c) the occurrence of uveitis up to 3 years after inclusion in ICON in relation to the $25(\mathrm{OH}) \mathrm{D}$ level were investigated.

Serum 25(OH)D levels were compared by the paired $t$ test, and the categories of serum 25(OH)D levels between patients and controls were compared by conditional logistic regression analyses. The association between disease activity and 25(OH)D level was assessed by linear regression analysis. The association between the likelihood of uveitis and serum 25(OH)D, including the covariates of prior methotrexate (MTX) therapy and established uveitis risk factors, such as age at JIA onset, female sex, oligoarticular JIA onset, and ANA positivity, were analyzed using a multivariable Cox proportional hazard model. Multivariable logistic regression analysis was used to investigate the proportion of oligoarthritis patients who progressed to extended oligoarthritis until the 3-year follow up, with serum $25(\mathrm{OH}) \mathrm{D}$ as a predictor. $P$ values $<0.05$ were considered statistically significant. The data were analyzed using SAS software version 9.4 (SAS Institute, In der Neckarhelle 162, 69,118 Heidelberg).

\section{Results}

The subgroup of patients whose $25(\mathrm{OH}) \mathrm{D}$ levels were analyzed did not differ from the whole ICON study population in terms of the male-to-female ratio, age at study inclusion or symptom onset and ILAR category (Table 1). Migration background was found in $28.1 \%$ of the study population.

The mean 25(OH)D levels and the distribution of deficient and sufficient 25(OH)D levels in the study population and control subjects are summarized in Table 2. Mean 25(OH)D (first serum sample) in patients was insufficient and was slightly, although significantly, higher than that from matched subjects from KIGGS $(22.8 \mathrm{ng} / \mathrm{ml}$ (SD 10.3) and $19.6 \mathrm{ng} / \mathrm{ml}$ (SD 11.2), respectively, $p<0.001$ ). Nearly half of the patients $(44 \%)$ had a deficient $25(\mathrm{OH}) \mathrm{D}$ level in the first serum sample.

Table 1 Demographic and clinical data of the ICON study population

\begin{tabular}{|c|c|c|}
\hline & ICON patients with $25(\mathrm{OH}) \mathrm{D}$ measurement & All patients of the ICON study \\
\hline Number & 360 & 954 \\
\hline Female (\%) & 67.5 & 67.2 \\
\hline Age at study inclusion, years, mean (SD) & $7.1(4.6)$ & $7.9(4.8)$ \\
\hline Duration between symptom onset and diagnosis, months, median (IQR) & $3(2-7)$ & $3(1-6)$ \\
\hline Duration between diagnosis and ICON enrollment, months, median (IQR) & $1.4(0.5-4.4)$ & $1.5(0.4-4.7)$ \\
\hline \multicolumn{3}{|l|}{ Patients } \\
\hline - on DMARD at inclusion, $n(\%)$ & $178(49)$ & $471(49)$ \\
\hline - on MTX at inclusion, $n(\%)$ & $164(46)$ & $441(46)$ \\
\hline - on biologic drug at inclusion, $n(\%)$ & $14(4)$ & $49(5)$ \\
\hline \multicolumn{3}{|l|}{ Median (IQR) duration (months) of } \\
\hline - DMARD use at inclusion & $1.2(0.5-3.4)$ & $1.2(0.5-3.5)$ \\
\hline - MTX use at inclusion & $1.2(0.5-3.5)$ & $1.2(0.5-3.4)$ \\
\hline - Biologic drug use at inclusion & $1.1(0.4-2.9)$ & $0.9(0.3-2.9)$ \\
\hline \multirow[t]{2}{*}{ ANA positive at study inclusion, $n(\%)$} & $228(63)$ & $517(54)$ \\
\hline & ILAR category, $n(\%)$ & ILAR category, n (\%) \\
\hline Systemic arthritis & $15(4)$ & $35(4)$ \\
\hline Oligoarthritis & $173(48)$ & $445(47)$ \\
\hline Psoriatic arthritis & $18(5)$ & $39(4)$ \\
\hline Enthesitis-related arthritis & $30(8)$ & $100(11)$ \\
\hline Polyarthritis, rheumatoid factor positive & $5(1)$ & $15(2)$ \\
\hline Polyarthritis, rheumatoid factor negative & $96(27)$ & $252(26)$ \\
\hline Other arthritis & $23(6)$ & $68(7)$ \\
\hline
\end{tabular}

ICON Inception cohort of newly diagnosed patients with juvenile idiopathic arthritis, $25(\mathrm{OH}) \mathrm{D}: 25(\mathrm{OH})$ vitamin $\mathrm{D}, S D$ standard deviation, IQR interquartile range, $D M A R D$ disease-modifying antirheumatic drug, MTX methotrexate, ANA antinuclear antibody, ILAR International League of Associations for Rheumatology 
Table 2 Comparison of 25(OH)D levels in patients from ICON and subjects from the KIGGS study and number/proportion of patients with a stable deficient or stable sufficient 25(OH)D status

\begin{tabular}{|c|c|c|c|c|c|c|}
\hline & \multicolumn{3}{|c|}{ ICON patients, first sample } & \multicolumn{3}{|c|}{ KIGGS subjects } \\
\hline & $\begin{array}{l}25(\mathrm{OH}) \mathrm{D} \mathrm{ng} / \mathrm{ml} \\
\text { mean }(\mathrm{SD})\end{array}$ & $\begin{array}{l}\text { 25(OH)D deficient } \\
(<20 \mathrm{ng} / \mathrm{ml}) \\
\text { Number }(\%)\end{array}$ & $\begin{array}{l}25(\mathrm{OH}) \mathrm{D} \text { sufficient } \\
(\geq 30 \mathrm{ng} / \mathrm{ml}) \\
\text { Number }(\%)\end{array}$ & $\begin{array}{l}25(\mathrm{OH}) \mathrm{D} \\
\mathrm{ng} / \mathrm{ml} \\
\text { mean (SD) }\end{array}$ & $\begin{array}{l}\text { 25(OH)D deficient } \\
(<20 \mathrm{ng} / \mathrm{ml}) \\
\text { Number }(\%)\end{array}$ & $\begin{array}{l}25(\mathrm{OH}) \mathrm{D} \text { sufficient } \\
(\geq 30 \mathrm{ng} / \mathrm{ml}) \\
\text { Number }(\%)\end{array}$ \\
\hline All $(n=360)$ & $22.8(10)$ & $158(44)$ & $75(21)$ & $19.6(11)$ & $221(62)$ & $57(16)$ \\
\hline Male $(n=117)$ & $22.7(10)$ & $54(49)$ & $26(24)$ & $18.5(11)$ & $68(62)$ & $14(13)$ \\
\hline \multirow[t]{3}{*}{ Female $(n=243)$} & $22.8(10)$ & $104(42)$ & $49(20)$ & $20.1(11)$ & $153(62)$ & $43(17)$ \\
\hline & \multicolumn{6}{|c|}{ ICON patients, both samples } \\
\hline & $\begin{array}{l}25(\mathrm{OH}) \mathrm{D} \mathrm{ng} / \mathrm{ml} \\
\text { mean }(\mathrm{SD})\end{array}$ & $\begin{array}{l}\text { Stable } 25(\mathrm{OH}) \mathrm{D} \text { deficient } \\
(2<20 \mathrm{ng} / \mathrm{ml}) \\
\text { Number }(\%)\end{array}$ & $\begin{array}{l}\text { Stable } 25(\mathrm{OH}) \text { D sufficient } \\
(2 \geq 30 \mathrm{ng} / \mathrm{ml}) \\
\text { Number }(\%)\end{array}$ & & & \\
\hline All $(n=360)$ & $22.1(8)$ & $87(25)$ & $23(7)$ & & & \\
\hline Male $(n=117)$ & $22.2(8)$ & $29(25)$ & $8(7)$ & & & \\
\hline Female $(n=243)$ & $22.1(8)$ & $58(24)$ & $15(6)$ & & & \\
\hline \multicolumn{7}{|l|}{ ILAR categories } \\
\hline Systemic JIA $(n=15)$ & $21.8(12)$ & $5(33)$ & $2(13)$ & & & \\
\hline Oligoarthritis $(n=173)$ & $23.3(8)$ & $29(17)$ & $14(8)$ & & & \\
\hline $\begin{array}{l}\text { Polyarthritis, rheumatoid } \\
\text { factor negative }(n=96)\end{array}$ & $20.9(8)$ & $32(33)$ & $4(4)$ & & & \\
\hline $\begin{array}{l}\text { Polyarthritis, rheumatoid } \\
\text { factor positive }(n=5)\end{array}$ & $23.7(9)$ & $1(20)$ & $1(20)$ & & & \\
\hline $\begin{array}{l}\text { Enthesitis-related } \\
\text { arthritis }(n=30)\end{array}$ & $21.1(6)$ & $8(27)$ & $1(3)$ & & & \\
\hline $\begin{array}{l}\text { Psoriatic arthritis } \\
(n=18)\end{array}$ & $22.4(7)$ & $6(33)$ & $0(0)$ & & & \\
\hline Other arthritis $(n=23)$ & $20.3(8)$ & $8(35)$ & $2(9)$ & & & \\
\hline $\begin{array}{l}\text { Patients with uveitis } \\
(n=61)\end{array}$ & $20.9(7)$ & $17(28)$ & $2(3)$ & & & \\
\hline $\begin{array}{l}\text { Patients without uveitis } \\
(n=299)\end{array}$ & $22.4(8)$ & $72(24)$ & $22(7)$ & & & \\
\hline $\begin{array}{l}\text { ANA positive patients } \\
(n=228)\end{array}$ & $22.4(8)$ & $54(24)$ & $14(6)$ & & & \\
\hline $\begin{array}{l}\text { ANA negative patients } \\
(n=120)\end{array}$ & $21.6(8)$ & $32(27)$ & $9(8)$ & & & \\
\hline
\end{tabular}

\section{5(OH)D level, disease activity and therapy}

We hypothesized that an effect of the vitamin D status later in the disease course might be abrogated by already established therapy. Thus, we used the 25(OH)D level from the first measured sample to analyze possible correlation with disease activity because at this time point, the patients were in an early phase of disease (median disease duration at that time 6.6 (IQR 3.8-11.4) months) and any treatment was initiated only briefly (212 (59\%) treated with disease modifying anti-rheumatic drugs (DMARDs), 195 (54\%) with MTX, and 18 (5\%) with biologic disease-modifying anti-rheumatic drugs (bDMARDs); median therapy duration 1.0 (IQR 0.5-3.5) month). We identified negative correlation between disease activity and the $25(\mathrm{OH}) \mathrm{D}$ level (Fig. 1a), which became more pronounced when we analyzed DMARD-naïve patients (Fig. 1b) and only patients with polyarthritis $(n=71, \beta=-0.38 ; 95 \%$ CI $-0.65 ;-0.11$; $p=0.007)$.

While in patients receiving $(n=208)$ and not receiving $(n=152)$ conventional synthetic disease modifying antirheumatic drugs (csDMARDs) at the first measurement, the mean 25(OH)D level did not differ significantly $(22.2$ $\mathrm{ng} / \mathrm{ml}$, SD 10.1 and $23.8 \mathrm{ng} / \mathrm{ml}$, SD 10.5, respectively), patients receiving systemic glucocorticoid therapy $\geq 0.2 \mathrm{mg} /$ kg body weight prednisolone equivalent $(n=19)$ had significantly lower mean $25(\mathrm{OH}) \mathrm{D}$ than patients $(n=275)$ without such systemic glucocorticoid doses $(16.4 \mathrm{ng} / \mathrm{ml}$, SD 9.4 and $23.0 \mathrm{ng} / \mathrm{ml}, \mathrm{SD} 10.1$, respectively, $p=0.014$ ). Patients with $25(\mathrm{OH}) \mathrm{D}<20 \mathrm{ng} / \mathrm{ml}$ in the first measurement received systemic glucocorticoids $\geq 0.2 \mathrm{mg} / \mathrm{kg}$ body weight prednisolone equivalent $(n=12,7.6 \%)$ and csDMARDs $(n=102,64.2 \%)$ a little more frequently at 


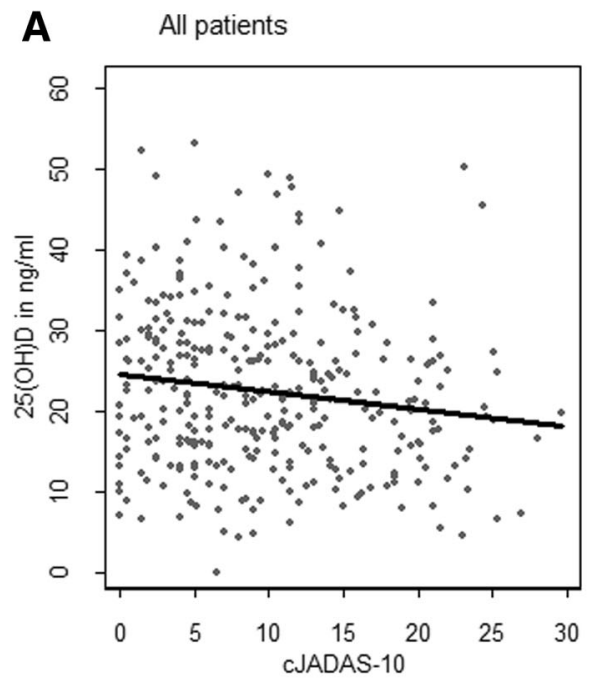

$n=329, \beta=-0.21$
$95 \% \mathrm{Cl}:-0.37$ to -0.05 $\mathrm{p}=0.001$

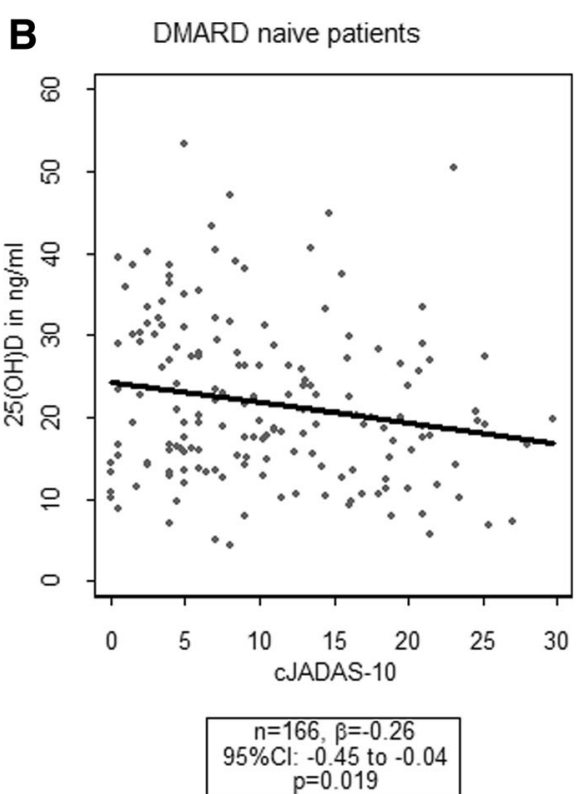

Fig. 1 Association between Clinical Juvenile Arthritis Disease Activity Score (cJADAS-10) and 25-hydroxy-vitamin D (25(OH)D) level at first measurement. DMARD, disease-modifying anti-rheumatic drug

this time than patients with $25(\mathrm{OH}) \mathrm{D}>30 \mathrm{ng} / \mathrm{ml}(n=2$, $2.6 \%$ and $n=44,56.4 \%$, respectively); these results were not statistically significant.

\section{5(OH)D deficiency in the ILAR categories}

Mean 25(OH)D of the two serum samples from each patient was insufficient $(22.1 \mathrm{ng} / \mathrm{ml}$ (SD 7.8)), with no differences between the sexes. Between the individual ILAR categories, mean $25(\mathrm{OH}) \mathrm{D}$ did not vary significantly, while the highest percentage of stable $25(\mathrm{OH}) \mathrm{D}$ deficiency was in patients with systemic, psoriatic and rheumatoid factor (RF)-negative polyarticular JIA (Table 2).

\section{Risk of developing extended oligoarthritis or uveitis}

We compared patients with a stable deficient $25(\mathrm{OH}) \mathrm{D}$ level to those with a stable sufficient $25(\mathrm{OH}) \mathrm{D}$ level in terms of the development of the extended form of oligoarthritis or the occurrence of uveitis. Overall, 62 of the 173 patients (36\%) with oligoarthritis developed an extended disease course until the 3-year follow up; 18 of these patients already had extended oligoarthritis at the time of enrollment. Twelve of the 29 patients (41\%) with oligoarthritis and a stable deficient 25(OH)D level and 2 of the 14 patients (14\%) with oligoarticular disease and a stable sufficient $25(\mathrm{OH}) \mathrm{D}$ level developed the extended form of disease in the first 3 years in ICON ( $p=0.034$, Fig. 2). This result was not corroborated by the multivariable analysis.

Altogether, 61 of the 360 patients (17\%) developed uveitis by the 3-year follow up: 10 of these patients developed uveitis before enrollment and 51 patients developed uveitis during the first 3 years in ICON. The majority had oligoarticular disease (54\% persistent/13\% extended), followed by RF-polyarthritis (21\%). Of the 87 patients with a stable deficient 25(OH)D level, $17(20 \%)$ developed uveitis, whereas only 2 of the 23 patients (9\%) with a stable sufficient 25(OH)D level did so ( $p=0.189$, Fig. 2$)$. In the multivariable regression analysis, we showed that the $25(\mathrm{OH}) \mathrm{D}$ level was significantly associated with the risk of developing uveitis (Table 3). For every $1 \mathrm{ng} / \mathrm{ml}$ increase in $25(\mathrm{OH}) \mathrm{D}>22.1 \mathrm{ng} /$ $\mathrm{ml}$ (the mean of the cohort), there was a $5 \%$ reduction in the risk of developing uveitis. This correlation persisted when we limited the examination to patients with uveitis who had blood drawn for 25(OH)D determination prior to developing uveitis (HR 0.95, 95\% CI 0.92; 1.00, $p=0.03$ ).

\section{Discussion}

In this study, in which vitamin D level was repeatedly prospectively measured in patients observed as standard, with recent-onset JIA, the following clinically relevant findings were ascertained:

- Vitamin D deficiency was common in patients with JIA and even more common in their peers from the general population

- 25(OH)D deficiency was associated with higher JIA disease activity

- The progression from oligoarthritis to an extended disease course occurred more often in patients with $25(\mathrm{OH}) \mathrm{D}$ deficiency than in those with $25(\mathrm{OH}) \mathrm{D}$ sufficiency

- The 25(OH)D level was inversely correlated with the risk of developing JIA-associated anterior uveitis 


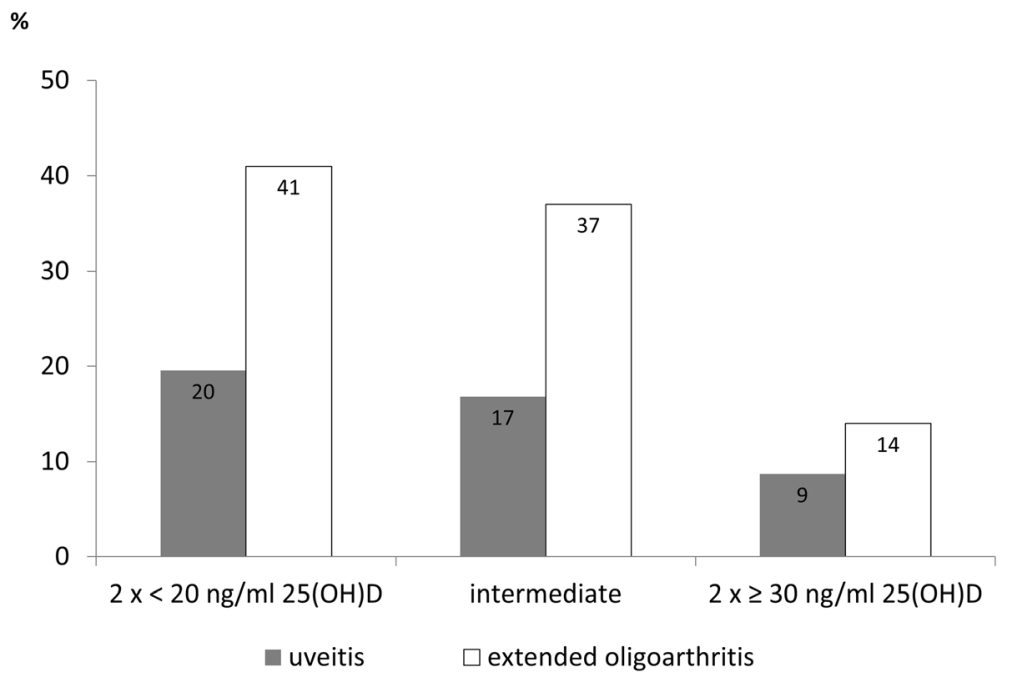

Fig. 2 Proportion of patients with stable deficient or stable sufficient 25-hydroxy-vitamin D (25(OH)D) status who developed uveitis or the extended form of oligoarthritis up to the 3-year follow up

Pelajo et al. also identified a high prevalence of vitamin D deficiency when they measured $25(\mathrm{OH}) \mathrm{D}$ in children and adolescents with rheumatologic diseases and in children with non-autoimmune disorders (e.g., noninflammatory disorders, infectious diseases, pain amplification syndrome) as controls [15]. The risk of vitamin D deficiency was significantly higher in patients with autoimmune disorders (OR 2.3) than in patients with non-autoimmune diseases; however, no significant differences in the mean 25(OH)D levels between these two patient groups were observed. Our finding that vitamin $\mathrm{D}$ deficiency is even more common in control subjects than in patients with JIA is somehow unexpected and cannot be easily explained because we controlled for the possible influencing factors by matching for age, sex, migration background and even the month of blood sampling.

Possibly patients with JIA are screened more frequently for vitamin $\mathrm{D}$ deficiency in the course of clinical routine and might consequently receive vitamin $\mathrm{D}$ supplements. Pepmueller et al. assessed parameters of bone mineralization in patients with JIA and also found that mean $25(\mathrm{OH}) \mathrm{D}$ in patients $(28.2 \mathrm{ng} / \mathrm{ml})$ was significantly higher than in healthy controls $(22.0 \mathrm{ng} / \mathrm{ml})$ [16].

We identified significant negative correlation between the $25(\mathrm{OH}) \mathrm{D}$ level from the first serum sample and JIA activity, as measured by the cJADAS-10. Pelajo et al. did not find this association in their cross-sectional study of 154 patients with JIA but noted that the included patients had established ongoing disease and that the majority had received some kind of disease-modifying treatment [17]. In a subset analysis of newly diagnosed patients with JIA, they identified negative association between the serum 25(OH)D levels and the JADAS-27, but this result was not statistically significant. In our study, there was an inverse relationship between $25(\mathrm{OH}) \mathrm{D}$ and disease activity that was even more pronounced in DMARD-naive subjects. Van Hamburg et al. showed that TNF-alpha blockade alone was insufficient

Table 3 Risk of developing uveitis in relation to $25(\mathrm{OH}) \mathrm{D}$ level (mean of both measurements) and other parameters

\begin{tabular}{|c|c|c|c|c|c|}
\hline & $\begin{array}{l}\text { Patients with uveitis } \\
n=61\end{array}$ & $\begin{array}{l}\text { Patients without uveitis } \\
n=299\end{array}$ & Hazard ratio & $95 \% \mathrm{Cl}$ & $p$ value \\
\hline 25(OH)D level, mean (SD), ng/ml & $21.0(6.8)$ & $22.4(8.0)$ & 0.95 & $0.91 ; 0.99$ & 0.022 \\
\hline Female sex, $n(\%)$ & $45(74)$ & $198(66)$ & 1.32 & $2.56 ; 0.68$ & 0.414 \\
\hline Age at JIA onset, mean (SD), years & $4.0(2.9)$ & $7.8(4.6)$ & 0.84 & $0.77 ; 0.93$ & 0.001 \\
\hline Oligoarticular JIA onset, $n$ (\%) & $41(67)$ & $132(44)$ & 1.20 & $0.60 ; 2.41$ & 0.601 \\
\hline ANA positivity at study inclusion, $n(\%)$ & $58(95)$ & $170(57)$ & 5.07 & $1.50 ; 17.15$ & 0.009 \\
\hline CJADAS-10 (range 0-30), mean (SD) & $5.9(3.9)$ & $4.8(3.2)$ & 1.22 & $1.14 ; 1.31$ & $<0.001$ \\
\hline MTX treatment ${ }^{\mathrm{b}}, n(\%)$ & $31(51)$ & $235(79)$ & 0.29 & $0.15 ; 0.57$ & $<0.001$ \\
\hline
\end{tabular}

25(OH)D 25(OH) vitamin D, JIA juvenile idiopathic arthritis, ANA antinuclear antibodies, MTX methotrexate, cJADAS Clinical Juvenile Arthritis Disease Activity Score ${ }^{a}$ CJADAS-10: mean score in patients with uveitis were calculated until occurrence of uveitis, in patients without uveitis mean cJADAS-10 score was calculated until 3-year follow up

${ }^{b}$ MTX: patients with uveitis, ever treated with MTX until occurrence of uveitis; patients without uveitis, ever treated until 3-year follow up 
to suppress the production of interleukin (IL)-17A and IL-22, which are two key cytokines involved in the pathophysiologic interaction of T helper 17 (Th17) cells and synovial fibroblasts in RA. Only in combination with $1,25(\mathrm{OH})_{2} \mathrm{D}_{3}$ did TNF-alpha blockade synergistically suppress inflammatory mediators in RA synovial fibroblast cocultures [18].

We did not observe significant differences in mean $25(\mathrm{OH}) \mathrm{D}$ between the JIA categories, but the proportion of $25(\mathrm{OH}) \mathrm{D}$-deficient patients differed among the subgroups. Similar to the work by Stagi et al. [19], we identified the highest percentage of vitamin D deficiency in patients with systemic and polyarticular JIA. Whether this finding is somehow specific to a particular JIA category or whether it is the result rather than the cause of disease severity cannot be deduced from our data.

Analyzing the disease course and outcomes of JIA, we observed a higher proportion of stable $25(\mathrm{OH}) \mathrm{D}$-deficient patients with oligoarthritis who developed an extended disease course during the first 3 years in ICON than of patients with oligoarthritis and a stable sufficient $25(\mathrm{OH}) \mathrm{D}$ level. To our knowledge, this association has not been described before, and it requires further investigation.

One of the most relevant extra-articular manifestations of JIA is anterior uveitis, which is frequently associated with complications and can be accompanied by visual impairment. We confirmed the known risk factors for the development of anterior uveitis in patients with JIA, including ANA positivity, young age at JIA onset and no prior treatment with methotrexate [20]. A new finding in our study was that a higher percentage of patients with JIA with stable deficient $25(\mathrm{OH}) \mathrm{D}$ developed uveitis until the 3-year follow up than did patients with a stable sufficient $25(\mathrm{OH}) \mathrm{D}$ level. The odds of developing uveitis were $5 \%$ lower for every $1 \mathrm{ng} / \mathrm{ml}$ increase in $25(\mathrm{OH}) \mathrm{D}$. As far as we know, this result has not been previously described in childhood uveitis and may be of great interest in predicting and possibly preventing JIA-associated uveitis. Grotting et al. compared 100 adult patients with and without non-infectious anterior uveitis and demonstrated that hypovitaminosis $\mathrm{D}$ (defined as $25(\mathrm{OH}) \mathrm{D}<30$ $\mathrm{ng} / \mathrm{ml}$ ) was associated with this disease, and the odds of developing uveitis were $4 \%$ lower for every $1 \mathrm{ng} / \mathrm{ml}$ increase in 25(OH)D [21]. Mitulescu et al. analyzed the influence of vitamin $\mathrm{D}$ in patients with ankylosing spondylitis in terms of the development of acute anterior uveitis (AAU) and showed an association between low 25(OH)D and AAU accompanied by increased IL- 8 and serum amyloid A as markers of the inflammatory response [22]. Yi et al. showed that in patients with Vogt-Koyanagi-Harada disease, a type of autoimmune pan-uveitis, $1,25(\mathrm{OH})_{2} \mathrm{D}_{3}$ was significantly lower in patients with active disease than in patients with inactive disease and in controls. Moreover, they demonstrated that the incubation of peripheral blood mononuclear cells (PBMC) with $1,25(\mathrm{OH})_{2} \mathrm{D}_{3}$ resulted in reduced proliferation of $\mathrm{PBMC}$ and reduced production of IFN- and IL-17A in the presence of anti-CD3 and anti-CD28 [23], suggesting that vitamin $\mathrm{D}$ supplementation might be an adjunctive treatment option for patients with this form of uveitis.

As a large amount of in vitro data has shown the anti-inflammatory and antiproliferative effects of vitamin D on immune cells [1], a causal link between low 25(OH)D and autoimmune diseases is plausible. However, low $25(\mathrm{OH}) \mathrm{D}$ might also be the result rather than the cause of the underlying inflammation in these diseases because it has been shown that $25(\mathrm{OH}) \mathrm{D}$ decreases during the acute-phase response parallel to the increase in $\mathrm{C}$ reactive protein after surgery [24]. Therefore, Welsh et al. investigated whether the administration of a TNF- $\alpha$ blocker - and thereby reduction of the inflammatory reaction in patients with RA - changes the 25(OH)VD levels. They observed a significant improvement in the Disease Activity Score in 28 joints (DAS28) and a decrease in erythrocyte sedimentation rate (ESR), while median $25(\mathrm{OH}) \mathrm{D}$ remained unchanged after treatment with adalimumab [25].

To date, only a few papers have described the effects of vitamin $\mathrm{D}$ supplementation in children with autoimmune diseases. Reed et al. examined the effect of $25(\mathrm{OH}) \mathrm{D}$ supplementation at $1-2 \mu \mathrm{g} / \mathrm{kg}$ body weight/day over 1 year in 13 children with active polyarticular JIA and described a significant increase in $25(\mathrm{OH}) \mathrm{D}$, but did not observe change in disease activity with this regimen [26]. By contrast, Lima et al. performed a study in adolescents and young adults with systemic lupus erythematosus and showed that the increase in the $25(\mathrm{OH}) \mathrm{D}$ was accompanied by reduced disease activity and fatigue and decreased frequency of anti-double stranded (ds)DNA antibodies after 24 weeks of supplementation with 50,000 IU of cholecalciferol per week [27].

\section{Conclusion}

Our study revealed that vitamin D deficiency is common in patients with JIA, although the prevalence was lower than in matched subjects from the general population. In patients with JIA, vitamin D deficiency is associated with higher disease activity and a higher risk of developing uveitis and possibly the extended form of oligoarthritis. The strength of this study is the prospective controlled design with standardized data ascertainment. A limitation of this study is that the any use of vitamin D supplementation was not recorded. To further clarify if cholecalciferol substitution in order to achieve a sufficient $25(\mathrm{OH}) \mathrm{D}$ level might have the potential to prevent the development of uveitis and the extended form of oligoarthritis, these associations must be confirmed by an interventional study. 


\section{Abbreviations}

25(OH)D: 25-Hydroxy-vitamin D; AAU: Acute anterior uveitis; ANA: Antinuclear antibodies; bDMARD: Biologic disease-modifying antirheumatic drug; CD: Cluster of differentiation; Cl: Confidence interval; CJADAS: Clinical Juvenile Arthritis Disease Activity Score; CRP: C-reactive protein; CsDMARD: Conventional synthetic disease-modifying antirheumatic drug; DMARD: Disease-modifying antirheumatic drug; FU: Follow up; ICON: Inception cohort of patients with newly diagnosed juvenile idiopathic arthritis; IFN-y: Interferon gamma; IL: Interleukin; ILAR: International League of Associations for Rheumatology; IQR: Interquartile range; JIA: Juvenile idiopathic arthritis; KIGGS: German National Health Interview and Examination Survey for Children and Adolescents; MTX: Methotrexate; NRS: Numeric rating scale; PBMC: Peripheral blood mononuclear cells; PTH: Parathyroid hormone; RA: Rheumatoid arthritis; RF: Rheumatoid factor; SD: Standard deviation; TNF-a: Tumor necrosis factor alpha

\section{Acknowledgements}

We would like to thank all physicians engaged in the ICON cohort, especially Tilmann Kallinich, Universitätsmedizin Charité Berlin; Hans-lko Huppertz, Prof.Hess-Kinderklinik, Bremen; Ivan Foeldvari, Kinderrheumatologische Praxis am AK Eilbek Hamburg; Jasmin Kümmerle-Deschner, Universität Tübingen; Ariane Klein, Asklepios Kinderklinik Sankt Augustin and Kirsten Mönkemöller, Kinderkrankenhaus der Stadt Köln.

We would like to thank Mrs P Rösgen and Dr. A.-B. Sundermann, Labor28, Berlin, for conducting the $25(\mathrm{OH}) \mathrm{D}$ measurement and discussing vitamin $\mathrm{D}$ reference values and B.-M. Kurth, Robert-Koch-Institut Berlin, for providing the data from the German National Health Interview and Examination Survey for Children and Adolescents (KIGGS).

We are especially grateful to all patients and their parents for their participation in ICON.

\section{Funding}

The ICON cohort is funded by the German Federal Ministry of Education and Research (BMBF, FKZ 01 ER 1504A, 01 ER 1504B, 01 ER 1504C).

\section{Availability of data and materials}

None.

\section{Authors' contributions}

Drs Sengler, Klotsche and Minden had full access to all of the data in the study and take responsibility for the integrity of the data and the accuracy of the data analysis. CS drafted the manuscript. The funding was obtained by $\mathrm{KM}, \mathrm{DF}, \mathrm{AH}, \mathrm{AZ}$. KM, MN, CS and JK, and AZ developed the study concept and design. Data were acquired by IL, JZ, MN, KM, CS, GH, CK, GG, AT, JPH, FWH, AH and DF. Data were analyzed and interpreted by JK, CS, GH, DF and KM. IL, CK and MN were responsible for the administrative, technical or material support. All authors critically revised the manuscript and approved the final submitted draft.

\section{Ethics approval and consent to participate}

The study protocol was approved by the ethics committee of the Charité Universitätsmedizin Berlin. Parents and patients from the age of 8 years gave their informed assent/consent for participation.

\section{Consent for publication}

Not applicable.

\section{Competing interests}

C Sengler, none; J Zink, none; J Klotsche, none; M Niewerth, none; I Liedmann, none; G Horneff has received honoraria from Novartis, Chugai, Boeringer, Celgene and BMS and research grants from AbbVie, Chugai, MSD, Novartis, Pfizer and Roche; G Ganser, none; A Thon, none; J-P Haas has received research support from Novartis and Pfizer; A Hospach has received consulting fees, speaking fees and/or honoraria from Chugai and Novartis (< US\$10,000 each); F Weller-Heinemann, none; A Heiligenhaus has received research grants from Pfizer and Novartis and honoraria from AbbVie, Alimera Sciences, Allergan, MSD Sharp and Dohme, Pfizer, Santen and Xoma; D Foell has received consulting fees, speaking fees and/or honoraria from ChugaiRoche, Sobi, Novartis and Pfizer (< US\$10,000 each) and research grants from Novartis and Pfizer; Drs Kessel and Foell have submitted a patent application relating to the use of proinflammatory S100A12 homomultimers in the diagnosis and treatment of inflammatory disorders (WO 2016/178154 A1); A Zink, none; K Minden has received honoraria (< US\$10.000) from AbbVie, Biermann, Chugai, Medac and Roche.

\section{Publisher's Note}

Springer Nature remains neutral with regard to jurisdictional claims in published maps and institutional affiliations.

\section{Author details}

${ }^{1}$ German Rheumatism Research Center, a Leibniz Institute, Charitéplatz 1 , 10117 Berlin, Germany. ${ }^{2}$ Institute for Social Medicine, Epidemiology and Health Economics, Charité Universitätsmedizin Berlin, Berlin, Germany. ${ }^{3}$ Center for General Pediatrics and Neonatology, Asklepios Klinik Sankt Augustin, Sankt Augustin, Germany. ${ }^{4}$ University hospital Cologne, Cologne, Germany. ${ }^{5}$ Department of Pediatric Rheumatology and Immunology, University of Münster, Münster, Germany. ${ }^{6}$ Clinic of Pediatric Rheumatology, St. Josef-Stift Hospital, Sendenhorst, Germany. ${ }^{7}$ Department of Pediatric Pneumology, Allergology and Neonatology, Children's Hospital, Medical School, Hanover, Germany. ${ }^{8}$ German Center for Pediatric and Adolescent Rheumatology, Garmisch-Partenkirchen, Germany. ${ }^{9}$ Olgahospital Kinderklinik, Stuttgart, Germany. ${ }^{10}$ Prof.-Hess-Kinderklinik, Bremen, Germany. ${ }^{11}$ Department of Ophthalmology and Ophtha-Lab at St. Franziskus Hospital, Muenster, Germany. ${ }^{12}$ University of Duisburg-Essen, Essen, Germany. ${ }^{13}$ Department of Rheumatology and Clinical Immunology, Charité Universitätsmedizin Berlin, Berlin, Germany.

Received: 24 August 2018 Accepted: 11 November 2018 Published online: 13 December 2018

\section{References}

1. Christakos S, Dhawan P, Verstuyf A, Verlinden L, Carmeliet G. Vitamin D: metabolism, molecular mechanism of action, and pleiotropic effects. Physiol Rev. 2016;96:365-408.

2. Nisar MK, Masood F, Cookson P, Sansome A, Ostor AJ. What do we know about juvenile idiopathic arthritis and vitamin D? A systematic literature review and meta-analysis of current evidence. Clin Rheumatol. 2013;32:729-34.

3. Sengler C, Klotsche J, Niewerth M, Liedmann I, Foll D, Heiligenhaus A, Ganser G, Horneff G, Haas JP, Minden K. The majority of newly diagnosed patients with juvenile idiopathic arthritis reach an inactive disease state within the first year of specialised care: data from a German inception cohort. RMD Open. 2015;1:e000074.

4. Petty RE, Southwood TR, Manners P, Baum J, Glass DN, Goldenberg J, He X, Maldonado-Cocco J, Orozco-Alcala J, Prieur AM, et al. International League of Associations for Rheumatology classification of juvenile idiopathic arthritis: second revision, Edmonton, 2001. J Rheumatol. 2004;31:390-2.

5. Heiligenhaus A, Niewerth M, Ganser G, Heinz C, Minden K. German Uveitis in Childhood Study Group. Prevalence and complications of uveitis in juvenile idiopathic arthritis in a population-based nation-wide study in Germany: suggested modification of the current screening guidelines. Rheumatology (Oxford). 2007;46:1015-9.

6. Kurth BM, Kamtsiuris $P$, Holling H, Schlaud M, Dolle R, Ellert U, Kahl H, Knopf $H$, Lange $M$, Mensink GB, et al. The challenge of comprehensively mapping children's health in a nation-wide health survey: design of the German KiGGS-Study. BMC Public Health. 2008;8:196.

7. Hintzpeter B, Scheidt-Nave C, Muller MJ, Schenk L, Mensink GB. Higher prevalence of vitamin $\mathrm{D}$ deficiency is associated with immigrant background among children and adolescents in Germany. J Nutr. 2008;138:1482-90.

8. Ross AC, Manson JE, Abrams SA, Aloia JF, Brannon PM, Clinton SK, DurazoArvizu RA, Gallagher JC, Gallo RL, Jones G, et al. The 2011 report on dietary reference intakes for calcium and vitamin D from the Institute of Medicine: what clinicians need to know. J Clin Endocrinol Metab. 2011;96:53-8.

9. Misra M, Pacaud D, Petryk A, Collett-Solberg PF, Kappy M. Drug, Therapeutics Committee of the Lawson Wilkins Pediatric Endocrine Society. Vitamin D deficiency in children and its management: review of current knowledge and recommendations. Pediatrics. 2008;122:398-417.

10. Munns C, Zacharin MR, Rodda CP, Batch JA, Morley R, Cranswick NE, Craig ME, Cutfield WS, Hofman PL, Taylor BJ, et al. Prevention and treatment of infant and childhood vitamin D deficiency in Australia and New Zealand: a consensus statement. Med J Aust. 2006;185:268-72.

11. Thomas MK, Lloyd-Jones DM, Thadhani RI, Shaw AC, Deraska DJ, Kitch BT, Vamvakas EC, Dick IM, Prince RL, Finkelstein JS. Hypovitaminosis D in medical inpatients. N Engl J Med. 1998;338:777-83. 
12. Chapuy MC, Preziosi P, Maamer M, Arnaud S, Galan P, Hercberg S, Meunier PJ. Prevalence of vitamin D insufficiency in an adult normal population. Osteoporos Int. 1997;7:439-43.

13. Holick MF, Binkley NC, Bischoff-Ferrari HA, Gordon CM, Hanley DA, Heaney RP, Murad MH, Weaver CM, Society E. Evaluation, treatment, and prevention of vitamin D deficiency: an Endocrine Society clinical practice guideline. J Clin Endocrinol Metab. 2011;96:1911-30.

14. McErlane F, Beresford MW, Baildam EM, Chieng SE, Davidson JE, Foster HE, Gardner-Medwin J, Lunt M, Wedderburn LR, Thomson W, et al. Validity of a three-variable Juvenile Arthritis Disease Activity Score in children with newonset juvenile idiopathic arthritis. Ann Rheum Dis. 2013;72:1983-8.

15. Pelajo CF, Lopez-Benitez JM, Miller LC. 25-Hydroxyvitamin D levels and vitamin $\mathrm{D}$ deficiency in children with rheumatologic disorders and controls. J Rheumatol. 2011;38:2000-4.

16. Pepmueller $\mathrm{PH}$, Cassidy JT, Allen SH, Hillman LS. Bone mineralization and bone mineral metabolism in children with juvenile rheumatoid arthritis. Arthritis Rheum. 1996;39:746-57.

17. Pelajo CF, Lopez-Benitez JM, Kent DM, Price LL, Miller LC, Dawson-Hughes B. 25-Hydroxyvitamin D levels and juvenile idiopathic arthritis: is there an association with disease activity? Rheumatol Int. 2012;32:3923-9.

18. van Hamburg JP, Asmawidjaja PS, Davelaar N, Mus AM, Colin EM, Hazes JM, Dolhain RJ, Lubberts E. Th17 cells, but not Th1 cells, from patients with early rheumatoid arthritis are potent inducers of matrix metalloproteinases and proinflammatory cytokines upon synovial fibroblast interaction, including autocrine interleukin-17A production. Arthritis Rheum. 2011;63:73-83.

19. Stagi S, Bertini F, Cavalli L, Matucci-Cerinic M, Brandi ML, Falcini F. Determinants of vitamin D levels in children, adolescents, and young adults with juvenile idiopathic arthritis. J Rheumatol. 2014;41:1884-92.

20. Tappeiner C, Schenck S, Niewerth M, Heiligenhaus A, Minden K, Klotsche J. Impact of antiinflammatory treatment on the onset of uveitis in Juvenile idiopathic arthritis: Iongitudinal analysis from a nationwide pediatric rheumatology database. Arthritis Care Res (Hoboken). 2016;68:46-54

21. Grotting LA, Davoudi S, Palenzuela D, Papaliodis GN, Sobrin L. Association of low vitamin D Levels with noninfectious anterior uveitis. JAMA Ophthalmol. 2017;135:150-3.

22. Mitulescu TC, Stavaru C, Voinea LM, Banica LM, Matache C, Predeteanu D. The role of Vitamin D in immuno-inflammatory responses in ankylosing spondylitis patients with and without acute anterior uveitis. J Med Life. 2016;9:26-33.

23. Yi X, Yang P, Sun M, Yang Y, Li F. Decreased 1,25-dihydroxyvitamin D3 level is involved in the pathogenesis of Vogt-Koyanagi-Harada (VKH) disease. Mol Vis. 2011;17:673-9.

24. Reid D, Toole BJ, Knox S, Talwar D, Harten J, O'Reilly DS, Blackwell S, Kinsella J, McMillan DC, Wallace AM. The relation between acute changes in the systemic inflammatory response and plasma 25-hydroxyvitamin D concentrations after elective knee arthroplasty. Am J Clin Nutr. 2011;93:1006-11.

25. Welsh P, Peters MJ, Mclnnes IB, Lems WF, Lips PT, McKellar G, Knox S, Michael Wallace A, Dijkmans BA, Nurmohamed MT, et al. Vitamin D deficiency is common in patients with RA and linked to disease activity, but circulating levels are unaffected by TNFalpha blockade: results from a prospective cohort study. Ann Rheum Dis. 2011;70:1165-7.

26. Reed A, Haugen M, Pachman LM, Langman CB. 25-Hydroxyvitamin D therapy in children with active juvenile rheumatoid arthritis: short-term effects on serum osteocalcin levels and bone mineral density. J Pediatr. 1991;119:657-60.

27. Lima GL, Paupitz J, Aikawa NE, Takayama L, Bonfa E, Pereira RM. Vitamin D supplementation in adolescents and young adults with juvenile systemic lupus erythematosus for improvement in disease activity and fatigue scores: a randomized, double-blind, placebo-controlled trial. Arthritis Care Res (Hoboken). 2016;68:91-8

Ready to submit your research? Choose BMC and benefit from:
- fast, convenient online submission
- thorough peer review by experienced researchers in your field
- rapid publication on acceptance
- support for research data, including large and complex data types
- gold Open Access which fosters wider collaboration and increased citations
- maximum visibility for your research: over 100M website views per year
At BMC, research is always in progress.
Learn more biomedcentral.com/submissions

